\begin{tabular}{|l|l|l||}
\hline \multicolumn{2}{|c|}{ PublisherInfo } \\
\hline \hline PublisherName & $:$ & BioMed Central \\
\hline \hline PublisherLocation & $:$ & London \\
\hline \hline PublisherImprintName & $:$ & BioMed Central \\
\hline \hline
\end{tabular}

\title{
Paul Silverman dies
}

\begin{tabular}{|l|l|l||}
\hline \multicolumn{2}{|c|}{ ArticleInfo } \\
\hline \hline ArticleID & $:$ & 4989 \\
\hline \hline ArticleDOI & $:$ & $10.1186 /$ gb-spotlight-20040805-01 \\
\hline \hline ArticleCitationID & $:$ & spotlight-20040505-01 \\
\hline \hline ArticleSequenceNumber & $:$ & 52 \\
\hline \hline ArticleCategory & $:$ & Research news \\
\hline ArticleFirstPage & $:$ & 1 \\
\hline \hline ArticleLastPage & $:$ & 3 \\
\hline \hline & & RegistrationDate : 2004-8-5 \\
\hline ArticleHistory & $:$ & OnlineDate \\
\hline \hline ArticleCopyright & $:$ & BioMed Central Ltd2004-8-5 \\
\hline \hline ArticleGrants & $:$ & \\
\hline \hline ArticleContext & $:$ & 130595511 \\
\hline \hline
\end{tabular}


Paul H. Silverman, founder of the first US human genome research center in Berkeley, Calif., and vocal advocate of stem cell research, died on July 15 due to complications following bone marrow replacement. He was 79.

During his five decades as a scientist and administrator, Silverman tackled issues ranging from immunotherapy to biotechnology. "His career is marked by so much diversity," said Susan Bryant, dean of biological sciences at the University of California, Irvine, where Silverman served as a professor. "He enjoyed different challenges and different topics, but he was always focused on big picture issues."

In 1987, Silverman helped establish the first human genome research center as a collaboration between the University of California, Berkeley, and the Department of Defense's Lawrence Livermore National Laboratory.

Silverman earned his $\mathrm{PhD}$ in parasitology and epidemiology from the University of Liverpool, $\mathrm{UK}$, in 1955. Following research in Israel and Scotland, he started the first immunoparasitology center at Glaxo Ltd. in London.

Before coming to Irvine, Silverman served on the faculty at the University of Illinois, Urbana, and as vice president of the University of New Mexico, provost and president of the research foundation at the State University of New York, and president of the University of Maine, Orono.

He was director of the western center of the American Academy of Arts and Sciences and was elected to the United Nations-supported World Academy of Art and Science in 1994. He also led the Biotechnology Research and Education Program for the University of California system and served as director of scientific affairs for Beckman Instruments and on the board of directors for Spectrum Pharmaceuticals.

He was appointed Irvine's associate vice chancellor for the Center for Health Sciences in 1992. "He worked both in industry and in academia at a time when not too many people made that transition back and forth," said Bryant. "He was a Renaissance man."

At the University of Maine, he strived to address the school's pressing financial needs and oversaw the construction of a new performing arts center, as well as delivered lectures on topics related to his own scientific research. Despite tensions with the chancellor at that time, "he was a much admired scientist, as well as an administrator," said Jim Horan, a retired professor of public administration who worked closely with Silverman during his presidency in Maine.

"He was much more appreciated after he left than when he was here," Horan added, "because people began to realize what he had done and what he had tried to do."

He also served on the board of directors for the Hastings Center and was involved with Irvine's interdisciplinary medical ethics program. "Paul was a consummate bioethicist," said former colleague Ron Miller, director emeritus of Irvine's medical ethics program. "It was obvious that he had a wealth of knowledge, not only scientific, but also in the ethics of science and the ethics of healthcare." 
Colleagues also described Silverman as a humanitarian and social activist. He was awarded a doctorate of human letters from his alma mater Roosevelt University, where in his commencement address to the Fall 2003 graduating class he spoke about discrimination against women and minorities. "He was, first and foremost, a man of enormous integrity both in science and in personal life," said Miller. "He was a warm, soft-spoken, humble man who touched many, many people."

In his later years, Silverman was "very concerned that scientists were slow in giving up the dogma of genetic determinism," said Miller. Silverman expressed his views on the subject this past May in The Scientist. The article "actually sparked a lot of correspondence," to Silverman, according to Bryant. "It struck a sympathetic cord in a lot of scientists, and he was thinking that he'd like to have an international symposium around the topic."

In recent years, Silverman was passionate about promoting public understanding of science. "[He] really tried to understand what people's concerns were, as well as help scientists to explain themselves better and just generally improve communication," said Bryant.

He focused much of his efforts on the issue of stem cell research. "He believed so strongly in it that he undertook stem cell transplantation [from his sister] himself for... myelofibrosis," Miller told us.

"Despite the enormous risks, especially to someone of his age, he undertook stem cell transplant hoping to restore his health, which had been severely compromised by anemia, requiring weekly blood transfusions." While the treatment did raise his white blood cell and platelet counts, related complications ultimately caused his death, said Miller.

Last May, Silverman helped plan a conference on stem cell research at the National Academies of Sciences and Engineering's Beckman Center, the proceedings of which will be published and may be dedicated to Silverman.

\section{References}

1. Commerce and genetic diagnosis

2. Commencement Address for Roosevelt University by Dr. Paul H. Silverman, December 20, 2003, [http://www.roosevelt.edu/graduation/2003-fall/commencementAddress.htm]

3. Silverman PH: Research vision: Rethinking genetic determinism The Scientist, 18:32-33, May 24, 2004., [http://www.the-scientist.com/yr2004/may/research3_040524.html] 